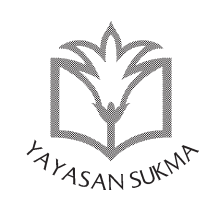

SUKMA: JURNAL PENDIDIKAN

ISSN: 2548-5105 (p), 2597-9590 (e)

Volume 2 Issue 1, Jan-Jun 2018, hlm. 137-166

https://jurnalsukma.org/index.php/sukma/article/view/02106

\title{
TENDENSI KESALAHAN SINTAKSIS BAHASA TULIS PEMBELAJAR BAHASA INDONESIA BAGI PENUTUR ASING (BIPA)*
}

Mokh. Yahya; Andayani; Kundharu Saddhono

Universitas Sebelas Maret Surakarta, Indonesia myahyabtg99@gmail.com

\section{Abstract}

Bahasa Indonesia is one of many languages arround the world that is in favor of foreigners (WNA). For them, bahasa Indonesia is learned for the certain goals. They are to academic purposes, profesion, and communication in daily life. For academic purposes, seeing that many foreign students learn bahasa Indonesia directly in Indonesia. One of the places is UPT Bahasa Universitas Sebelas Maret. The research is to present syntax error forms and their tendency error of written language

* Penulis mengucapkan terima kasih kepada Lembaga Pengelola Dana Pendidikan (LPDP) Kementerian Keuangan Republik Indonesia sebagai sponsor dalam penelitian ini. 
on TISOL students in academic level. The research is conducted in UPT Bahasa Universitas Sebelas Maret. It's subject is TISOL students whom study in Universitas Sebelas Maret Surakarta. This study is qualitative research in the form of case study. Researcher focuses on syntax level. It based on the interview toward the teacher. Many TISOL students did the syntax error on their written language.

[Bahasa Indonesia merupakan salah satu bahasa di dunia yang tengah digemari oleh Warga Negara Asing (WNA). Bagi WNA, bahasa Indonesia dipelajari untuk tujuan tertentu. Di antaranya untuk keperluan akademik, profesi, dan berkomunikasi dalam kehidupan sehari-hari. Untuk keperluan akademik, dapat dilihat dari maraknya mahasiswa asing yang belajar bahasa Indonesia secara langsung di Indonesia. Salah satunya di UPT Bahasa Universitas Sebelas Maret. Penelitian ini bertujuan untuk memaparkan bentuk-bentuk kesalahan sintaksis beserta tendensi kesalahannya pada bahasa tulis pembelajar Bahasa Indonesia bagi Penutur Asing (BIPA) tingkat akademik. Penelitian ini dilaksanakan di UPT Bahasa Universitas Sebelas Maret. Subjek penelitian dalam penelitian ini adalah pembelajar BIPA yang menempuh studi di UPT Bahasa Universitas Sebelas Maret Surakarta. Penelitian ini merupakan penelitian kualitatif yang berupa studi kasus. Dalam penelitian ini peneliti menekankan kajian pada tingkat sintaksis. Hal itu didasarkan pada wawancara terhadap pengajarnya. Menurutnya, banyak pembelajar BIPA yang melakukan kesalahan dalam bidang sintaksis pada bahasa tulisnya.]

Kata kunci: Pembelajar BIPA (TISOL students), tendensi kesalahan sintaksis (syntax error tendency), bahasa tulis (written language). 


\section{A. Pendahuluan}

Bahasa Indonesia makin giat dipelajari oleh Warga Negara Asing (WNA) untuk keperluan tertentu. Di antaranya untuk keperluan akademik, profesi, dan berkomunikasi dalam kehidupan sehari-hari. Untuk keperluan akademik, dapat dilihat dari maraknya mahasiswa asing yang belajar bahasa Indonesia secara langsung di Indonesia. Mereka mempelajari bahasa Indonesia terlebih dahulu sebelum menempuh pendidikan formal pada universitas yang diinginkannya. Pelatihan bahasa Indonesia bagi mahasiswa asing saat ini wajib dilakukan karena bahasa pengantar dalam pendidikan Indonesia adalah bahasa Indonesia. Hal ini tertuang dalam UU nomor 12 tahun 2012 tentang pendidikan tinggi pada paragraf 3 "bahasa pengantar" pasal 37 ayat 1 . Bunyi pasal dan ayat tersebut adalah sebagai berikut. "Bahasa Indonesia sebagai bahasa resmi negara wajib menjadi bahasa pengantar di perguruan tinggi." Oleh sebab itu, mahasiswa asing yang akan menempuh pendidikan di Indonesia dikumpulkan pada lembaga bahasa untuk diberi pelatihan bahasa Indonesia. Pelatihan itu mereka peroleh dalam tiga tahap, yaitu tingkat dasar, madya, dan mahir.

Tingkatan pelatihan tersebut muncul berkaitan erat dengan tujuan pembelajar asing mengikuti pembelajaran BIPA. Tujuan para penutur asing belajar bahasa Indonesia disesuaikan dengan konteksnya. Konteks di sini adalah keperluan atau kebutuhan dari penutur asing tersebut untuk belajar bahasa Indonesia. Kusmiatun $(2016,3)$ menyebutkan bahwa ada banyak tujuan para pembelajar BIPA saat mereka belajar bahasa Indonesia. Ada pembelajar BIPA yang belajar bahasa Indonesia dengan tujuan mampu berkomunikasi sehari-hari. Ada pula yang tujuannya lebih pada fokus dalam pekerjaan atau bidang yang digelutinya (orientasi pada pekerjaan). Bagi wisatawan asing, bahasa Indonesia yang dibutuhkan adalah bahasa Indonesia untuk jalan-jalan atau rekreasi. Tujuan lain dalam belajar bahasa Indonesia adalah tujuan akademik. Tingkat kemampuan pelajar BIPA berbeda-beda, mulai pelajar dengan tingkat pemula 
hingga dengan pelajar tingkat lanjut. Berdasarkan tingkatan kemampuan pelajar BIPA tersebut, muncul berbagai macam materi BIPA. Pada materi tersebut tercatat beberapa penulis buku, baik penulis asing maupun penulis Indonesia, yang menulis bahasa Indonesia untuk penutur asing.

Menurut Muliastuti dalam makalah yang disampaikan pada Konferensi Internasional Pengajaran Bahasa Indonesia Bagi Penutur Asing di Universitas Indonesia (2010), belajar berbahasa tidak sama dengan belajar tentang bahasa. Belajar berbahasa merujuk kepada belajar empat keterampilan berbahasa: menyimak, berbicara, membaca, dan menulis. Dalam belajar empat keterampilan tersebut, tentunya dibutuhkan pengetahuan tentang fonologi, morfologi, sintaksis, dan semantik bahasa yang sedang dipelajari. Hal yang tidak kalah pentingnya adalah budaya masyarakat pengguna bahasa tersebut, dalam hal ini kebudayaan Indonesia. Dengan demikian, pengajar BIPA harus dapat mengintegrasikan tiga hal tersebut dalam pengembangan materi. Ketidaktahuan siswa asing tentang budaya Indonesia dapat menimbulkan salah paham. Ketidaktahuan siswa tentang tata bahasa Indonesia akan menimbulkan pula kekacauan berbahasa. BIPA merupakan pembelajaran bahasa Indonesia yang subjeknya adalah pembelajar asing. BIPA dipandang lebih pada faktor pembelajarnya. Orang-orang yang menjadi subjek pembelajaran BIPA adalah orang asing, bukan penutur bahasa Indonesia (Kusmiatun 2016, 1).

Kesalahan berbahasa adalah bagian dari sebuah percakapan yang menyimpang dari beberapa norma atau aturan penggunaan bahasa yang dipilih (Dulay, Burt, dan Krashen 1982, 277). Kesalahan berbahasa adalah penyimpangan yang tampak pada tata bahasa penutur asli yang mencerminkan kompetensinya dalam berbahasa (Brown 1994, 205). Lebih jelas lagi, Setyawati (2010, 15-16) menjelaskan bahwa terdapat tiga kemungkinan penyebab seseorang salah dalam berbahasa. Dua penyebab kesalahan berbahasa tersebut terjadi pada diri pembelajar sendiri, sedangkan satu lainnya terjadi karena faktor eksternal pembelajar. Sintaksis adalah ilmu tentang bagaimana frasa dan kalimat tersusun 
atas kata (Radford 2004, 1). Dengan redaksi lain, sintaksis adalah ilmu tentang bagaimana kata yang satu bisa digabungkan dengan kata yang lain sehingga menjadi bentuk frasa dan kalimat (Radford 1998, 1). Batas kajian sintaksis meliputi frasa, klausa, dan kalimat. Berikut dipaparkan ketiga batas kajian sintaksis.

Berkaitan dengan bahasa, menurut Keraf $(1978,12)$, bahasa merupakan suatu sistem komunikasi yang mempergunakan simbol-simbol vokal yang arbitrer, yang dapat diperkuat dengan gerak-gerak badaniah yang nyata. Bahasa mencakup dua bidang, yaitu bunyi vokal yang dihasilkan oleh alat ucap manusia dan arti atau makna yang tersirat dalam rangkaian bunyi tadi. Bahasa sungguh memegang peranan penting dalam pola struktur kehidupan masyarakat yag beradab (Pamungkas 2012, 19). Melengkapi pendapat Keraf dan Pamungkas, Chaer $(1994,83)$ menjelaskan bahwa bahasa tulis merupakan "rekaman" bahasa lisan, sebagai usaha manusia untuk "menyimpan" bahasanya atau untuk bisa disampaikan kepada orang lain yang berada dalam ruang dan waktu yang berbeda. Bahasa tulis bukanlah bahasa lisan yang dituliskan seperti yang terjadi saat merekam bahasa lisan ke dalam pita rekaman. Berdasarkan penjelasan dari beberapa ahli, dapat disimpulkan bahwa bahasa tulis adalah ragam bahasa yang digunakan melalui media tulis dan dipelajari secara sadar.

Tingkat kemampuan pelajar BIPA berbeda-beda, mulai pelajar dengan tingkat pemula hingga dengan pelajar tingkat lanjut. Berdasarkan tingkatan kemampuan pelajar BIPA tersebut, muncul berbagai macam materi BIPA. Pada materi tersebut tercatat beberapa penulis buku, baik penulis asing maupun penulis Indonesia, yang menulis bahasa Indonesia untuk penutur asing. Menurut Muliastuti dalam makalah yang disampaikan pada Konferensi Internasional Pengajaran Bahasa Indonesia Bagi Penutur Asing di Universitas Indonesia (2010), belajar berbahasa tidak sama dengan belajar tentang bahasa. Belajar berbahasa merujuk kepada belajar empat keterampilan berbahasa: menyimak, berbicara, membaca, dan menulis. Dalam belajar empat keterampilan tersebut, tentunya dibutuhkan pengetahuan tentang fonologi, morfologi, sintaksis, dan semantik bahasa yang sedang dipela- 
jari. Hal yang tidak kalah pentingnya adalah budaya masyarakat pengguna bahasa tersebut, dalam hal ini kebudayaan Indonesia. Dengan demikian, pengajar BIPA harus dapat mengintegrasikan tiga hal tersebut dalam pengembangan materi. Ketidaktahuan siswa asing tentang budaya Indonesia dapat menimbulkan salah paham. Ketidaktahuan siswa tentang tata bahasa Indonesia akan menimbulkan pula kekacauan berbahasa.

Berkaitan dengan hal tersebut, Suyitno dalam pidato pengukuhan guru besar dalam bidang Ilmu Pembelajaran Bahasa pada Fakultas Sastra, Universitas Negeri Malang (2010) mengemukakan pengembangan materi budaya diarahkan pada pengenalan dan pengayaan wawasan budaya Indonesia kepada pelajar asing sehingga mereka dapat memanfaatkannya sebagai bekal dalam kehidupannya sehari-hari di masyarakat Indonesia. Pokok-pokok materi budaya yang perlu dikenalkan kepada pelajar BIPA adalah perilaku budaya, pengetahuan budaya, dan benda-benda budaya. Prinsip dalam pemberian materi budaya ini adalah membekali pelajar BIPA agar mampu berbahasa Indonesia sesuai dengan situasi dan kondisinya. Di samping itu, juga mengenalkan budaya Indonesia kepada pelajar BIPA sehingga dapat menumbuhkan sikap positif dan apresiatif pelajar BIPA terhadap budaya Indonesia.

Seperti yang dikatakan oleh Muliastuti (2010), pembelajar akan diberikan materi tata tingkat gramatikal, seperti fonologi, morfologi, sintaksis, dan wacana. Materi itu diberikan sebagai bekal dalam mempelajari empat keterampilan berbahasa Indonesia, yakni membaca, menulis, berbicara, dan menyimak. Di antara bagian-bagian dalam tata tingkat gramatikal, kesulitan belajar pembelajar BIPA terletak pada tiap-tiap bagian tersebut. Menurut Susanto (2007), kesulitan-kesulitan tersebut terjadi baik pada tataran pemahaman maupun pada tataran produksi. Kesulitan pada tataran pemahaman, misalnya kesulitan dalam memahami bunyi- bunyi dan urutan kata dalam kalimat bahasa Indonesia. Kesulitan dalam produksi, misalnya pada aspek pengucapan kata-kata bahasa Indonesia dan penulisan kata dan kalimat. Kesulitan-kesulitan yang dihadapi oleh pembelajar asing tersebut 
menyebabkan terjadinya bentuk-bentuk yang salah dalam bahasa Indonesia mereka. Andayani (2010, 112-122) menyampaikan bahwa para mahasiswa yang belajar BIPA berasal dari berbagai negara. Sebagai penutur asing bahasa Indonesia, mereka memiliki karakteristik tertentu, terutama tampak pada minat, tujuan belajar, strategi belajar, dan waktu belajar.

Paper ini ingin menekankan pentingnya kajian sintaksis dari para pembelajar BIPA karena banyaknya kasus kesalahan sintaksis yang dilakukan oleh mereka dalam bahasa tulisnya. Berdasarkan wawancara terhadap pengajar BIPA di UPT Bahasa Universitas Sebelas Maret Surakarta (UNS), kami memperoleh data bahwa kemampuan menulis kalimat mahasiswa pembelajar BIPA di lembaga tersebut sudah cukup baik. Namun beberapa mahasiswa memiliki kemampuan sintaksis dibawah rata-rata. Paper ini secara khusus berusaha mendeskripsikan fenomena tersebut secara rinci.

Secara metodologis, penelitian ini dilaksanakan di UPT Bahasa UNS dengan subjek penelitiannya para pembelajar BIPA di universitas tersebut. Penelitian ini merupakan penelitian kualitatif dengan pendekatan studi kasus. Studi kasus merupakan penelitian yang dilakukan untuk mengungkap suatu keadaan secara mendalam, intensif, baik mengenai perseorangan, secara individual, maupun kelompok, dan lembaga masyarakat (Mahmud 2011, 102). Strategi di dalam penelitian ini adalah studi kasus tunggal karena memfokuskan diri pada satu hal yakni kesalahan sintaksis bahasa tulis pembelajar BIPA yang belajar di UPT Bahasa UNS. Yule $(2014,318)$ menuturkan bahwa tulisan ialah representasi simbolik bahasa melalui penggunaan simbol-simbol grafis. Tulisan harus dipelajari melalui usaha sadar terus-menerus.

Data di dalam penelitian ini berupa informasi yang berkaitan dengan kajian kesalahan sintaksis pembelajar BIPA di UPT Bahasa UNS. Kendala-kendala dalam pembelajaran sintaksis termasuk dalam topik informasi dalam penelitian ini. Bagian terakhir dari informasi yang diambil yaitu solusi untuk mengatasi kendala tersebut. Jenis sumber data di dalam penelitian ini 
adalah informan atau narasumber, dokumen, dan peristiwa atau aktivitas. Penelitian ini menggunakan teknik pengumpulan data berupa wawancara, observasi atau pengamatan, dan analisis dokumen. Pengujian validitas data dalam penelitian ini dilakukan dengan cara triangulasi. Peneliti menggunakan triangulasi sumber data dan triangulasi metode.

Teknik analisis data di dalam penelitian ini menggunakan teknik analisis interaktif, yang dipahami sebagai proses penyusunan data agar dapat ditafsirkan (Nasution 1992, 126). Menurut Sutopo (2016, 114-116) analisis data dengan menggunakan teknik analisis interaktif terdiri atas tiga bagian setelah adanya pengumpulan data, yakni reduksi data, sajian data, dan penarikan simpulan dan verifikasi.

\section{B. Bentuk-Bentuk Kesalahan Sintaksis Bahasa Tulis Pembelajar BIPA}

Kesalahan berbahasa bahasa tulis pembelajar BIPA dalam bidang sintaksis dapat dikategorikan menjadi kesalahan dalam bentuk frasa dan kalimat. Kesalahan dalam bidang frasa dapat dijumpai pada komunikasi lisan maupun tertulis (Setyawati 2010, 75-102). Kesalahan-kesalahan tersebut dapat berupa: (1) adanya pengaruh bahasa daerah, (2) penggunaan preposisi yang tidak tepat, (3) kesalahan susunan kata, (4) penggunaan unsur yang berlebihan atau mubazir, (5) penggunaan bentuk superlatif yang berlebihan, (6) penjamakan yang ganda, dan (7) penggunaan resiprokal yang tidak tepat. Kesalahan sintaksis kedua adalah kesalahan dalam bidang kalimat. Kesalahan bidang kalimat berupa (1) kalimat tidak bersubjek, (2) kalimat tidak berpredikat, (3) kalimat tidak bersubjek dan berpredikat, (4) penggandaan subjek, (5) antara subjek dan predikat tersisipi unsur lain, (6) kalimat yang tidak logis, (7) kalimat yang ambigu, (8) penghilangan konjungsi, (9) penggunaan konjungsi yang berlebihan, (10) urutan yang tidak paralel, (11) penggunaan istilah asing, dan (12) penggunaan kata tanya yang tidak perlu.

Pembelajar BIPA di UPT Bahasa UNS berasal dari banyak 
negara. Di antaranya Filipina, Korea Selatan, Jepang, Vietnam, Timor Leste, Thailand, dan Mexico. Dari Filipina 1 mahasiswa, Korea Selatan 1 mahasiswa, Jepang 1 mahasiswa, Vietnam 4 mahasiswa, Timor Leste 1 orang, Thailand 1 mahasiswa, Mexico 1 mahasiswa, dan Polandia 1 mahasiswa.

Berdasarkan penelitian yang diakukan, ditemukan fakta bahwa pembelajar BIPA belum sepenuhnya memahami sintaksis bahasa Indonesia secara tepat. Temuan-temuan itu didasarkan pada sejumlah kesalahan pada tataran sintaksis yang ditemukan pada hasil kerja berupa karangan pembelajar BIPA. Peneliti menganalisis sejumlah karangan siswa yang dihasilkan saat pembelajaran.

Kesalahan sintaksis bahasa Indonesia pembelajar BIPA berupa pengaruh bahasa asing/daerah, penggunaan preposisi yang tidak tepat, kesalahan susunan kata, penggunaan unsur yang berlebihan atau mubazir, penjamakan yang ganda, dan penggunaan resiprokal yang tidak tepat, kalimat tidak bersubjek, kalimat tidak berpredikat, kalimat tidak bersubjek dan berpredikat, penggandaan subjek, antara subjek dan predikat tersisipi unsur lain, kalimat yang tidak logis, kalimat yang ambigu, penghilangan konjungsi, penggunaan konjungsi yang berlebihan, urutan yang tidak paralel, penggunaan istilah asing, dan ejaan.

Berikut dipaparkan bentuk-bentuk kesalahan sintaksis yang terdapat pada hasil kerja mahasiswa pembelajar BIPA.

\section{1) Kesalahan-kesalahan pada lembar kerja Subjek 1 dari Filipina:}

- penggunaan preposisi yang kurang tepat, misalnya dapat dijumpai pada kalimat: Setelah wawancara, membayar biaya visa atas kasir. Penggunaan preposisi atas dalam kalimat ini kurang tepat, seharusnya preposisi yang menyatakan tujuan, yaitu kepada. Kalimat tersebut dapat diperbaiki menjadi: Setelah wawancara, membayar biaya visa kepada kasir.

- penggunaan diksi yang kurang tepat. Kesalahan tersebut 
ditemukan pada kalimat: Membuat pendaftaran online. Penggunaan diksi membuat pada kalimat ini kurang tepat, sebaiknya diksi yang dipilih adalah melakukan.

- kesalahan ejaan, antara lain ditemukan pada kalimat: Tunggu 24 jam untuk mendapatkan nomor Anda. Dilihat dari konteksnya, ini adalah kalimat perintah, seharusnya digunakan tanda seru (!) untuk mengakhirinya, sehingga menjadi: Tunggu 24 jam untuk mendapatkan nomor Anda! Kesalahan ejaan juga ditemukan pada pengunaan koma dan huruf kapital pada kalimat: Sedap, Enak dan Lezat! Perincian yang lebih dari dua unsur harus didahului tanda koma sebelum kata dan. Penggunaan huruf kapital pada kata enak dan lezat juga harus diganti dengan huruf nonkapital karena kalimat tersebut bukan judul karangan. Kalimat ini dapat diperbaiki menjadi: Sedap, enak, dan lezat!

- penggunaan istilah asing yang ditemukan pada kata passport dan etc, yang seharusnya digunakan kata/istilah bahasa Indonesia: paspor dan dan lain-lain (dll.).

- kalimatyang tidakbersubjek dan predikat verba pasif, yang dapat ditemukan pada kalimat: Mudah untuk memasak ketika Anda lapar, yang belum memiliki subjek. Subjek bisa ditambahkan sesuai dengan konteksnya. Perbaikan kalimat tersebut adalah Indomie mudah untuk dimasak ketika Anda lapar.

- predikat berupa verba transitif tanpa objek, seperti pada kalimat: Durian berisi dan mempunyai biji warna coklat. Kalimat ini dapat diperbaiki dengan menambahkan objek sehingga menjadi: Durian berisi daging buah dan mempunyai biji warna coklat.

- kesalahan penggunaan konjungsi, seperti pada kalimat: Komposisi mi terdiri dari tepung terigu, minyak sayur, garam, pemantap, anti oksidan, penguat rasa (MSG). Dalam perincian beberapa unsur, seharusnya digunakan kata dan sebelum penyebutan unsur terakhir. 
- penggunaan kolokasi yang kurang tepat, misalnya pada frasa: terdiri dari. Dalam bahasa Indonesia baku, kolokasi yang baku adalah terdiri atas, bukan terdiri dari.

- susunan kalimat yang kurang tepat, seperti pada kalimat: Ada buah yang orang Nusa Tenggara sangat suka, namanya Durian. Susunan yang tepat adalah: Ada buah yang sangat disukai oleh orang Nusa Tenggara, namanya durian.

- kesalahan ejaan, seperti pada kalimat: Harganya cuma $R p$ 1,800. Sesuai dengan Pedoman Umum Ejaan Bahasa Indonesia (EBI) tahun 2015 penulisan lambang mata uang tidak diakhiri dengan tanda titik dan tidak ada spasi antara lambang itu dan angka yang mengikutinya, kecuali di dalam tabel. Dengan demikian, penulisan lambang mata uang seharunya: $R p 1.800,00$.

\section{2) Kesalahan-kesalahan pada lembar kerja Subjek 2 dari Korea Selatan:}

- penggunaan kata ganti yang kurang tepat, seperti pada klausa: warna badan itu putih. Sebaiknya kata ganti itu diganti dengan -nya. Agar lebih efektif, klausa tersebut bisa diubah susunannya menjadi badannya berwarna putih.

- penggunaan kata asing, yakni screen, seperti pada klausa: warna screen hitam. Dalam bahasa Indonesia, screen diterjemahkan menjadi layar.

- penggunaan konjungsi yang kurang tepat, seperti pada kalimat: Bentuknya persegi panjang tapi di pojok bengkok. Konjungsi tapi (tetapi) adalah konjungsi pertentangan yang penulisannya didahului tanda koma. Kalimat tersebut dapat diperbaiki menjadi: Bentuknya persegi panjang, tetapi di pojok bengkok.

- penggunaan diksi yang kurang tepat, seperti pada kalimat: Bentuknya persegi panjang tapi di pojok bengkok. Kata bengkok kurang tepat digunakan dalam kalimat tersebut, sebaiknya kata bengkok diganti dengan kata melengkung. 
Mokh. Yahya; Andayani; Kundharu Saddhono

3) Kesalahan-kesalahan pada lembar kerja Subjek 3 dari Jepang:

- kesalahan susunan frasa, seperti pada frasa menarik email dan menarik foto. Dalam bahasa Indonesia, susunan frasa berstruktur DM (Diterangkan-Menerangkan) sehingga susunan yang tepat adalah email (kata email di-Indonesiakan menjadi surel) menarik dan foto menarik.

- kalimatyang tidak efektif, seperti pada kalimat: Kamu, Matt dan Gino pakai apa di upacara perkawinan dan bagaimana caranya kalian tahu bahwa harus bilang kepada Fitra dan Fitri. Kalimat ini mengandung dua klausa, yaitu (1) kamu, Matt dan Gino pakai apa di upacara perkawinan dan (2) bagaimana caranya kalian tahu bahwa harus bilang kepada Fitra dan Fitri. Secara makna, klausa pertama sudah tepat, tetapi secara struktur, seharusnya kata pakai diganti dengan kata memakai karena verba aktif. Klausa kedua tidak jelas maksudnya. Sebaiknya, klausa kedua bisa diperjelas dengan bagaimana cara kalian bilang kepada Fitra dan Fitri. Secara struktur, kalimat tersebut merupakan kalimat pertanyaan, seharusnya tanda baca akhirnya adalah tanda tanya, bukan titik. Kalimat tersebut dapat diperbaiki menjadi Kamu, Matt, dan Gino memakai apa di upacara perkawinan dan bagaimana cara kalian bilang kepada Fitra dan Fitri? Agar lebih efektif, kalimat ini bisa dipisah menjadi dua kalimat.

- penggunaan kata asing, email dan moslem. Dalam bahasa Indonesia kata email diterjemahkan menjadi surel yang merupakan akronim dari surat elektronik. Seharusnya, kata moslem diganti dengan muslim karena sesuai dengan kata dalam bahasa Indonesia yang bermakna umat Islam.

- penggunaan konjungsi yang tidak tepat, seperti pada kalimat: Dan juga Apakah kalian ada kesempatan yang bisa lihat acara lain? Konjungsi dan tidak tepat digunakan untuk mengawali kalimat karena bukan konjungsi antarkalimat. Konjungsi dan dan kata juga bisa dihilangkan 
agar kalimat menjadi efektif.

\section{4) Kesalahan-kesalahan pada lembar kerja Subjek 4 dari Vietnam:}

- penggunaan kata-kata asing, yaitu photo-photo. Dalam bahasa Indonesia kata photo diserap menjadi foto, sehingga kata yang digunakan seharusnya foto.

- kalimat yang tidak efektif dan ambigu, seperti pada kalimat: Saya ingin tahu apa anda bertiga sudah memakai pakaian di perkawinan itu dan bagaimana anda tahu apa yang harus bilang dengan mempelai. Kalimat ini memiliki tiga klausa, yaitu (1) saya ingin tahu, (2) apa anda bertiga sudah memakai pakaian di perkawinan itu, dan (3) bagaimana anda tahu apa yang harus bilang dengan mempelai. Klausa (1) sudah tepat. Klausa (2) ambigu karena secara logika, orang yang menghadiri pernikahan pastilah sudah memakai pakaian. Mungkin maksudnya, dia ingin mengetahui pakaian yang dikenakan oleh "anda bertiga". Dalam bahasa Indonesia kata ganti orang kedua jamak adalah kalian sehingga frasa anda bertiga lebih baik diganti dengan kalian. Klausa (1) dapat diperbaiki menjadi saya ingin tahu pakaian apa yang dikenakan oleh kalian. Klausa (3) dapat diperbaiki menjadi apa yang harus dikatakan kepada mempelai.

- penjamakan yang ganda, seperti frasa beberapa fotofoto. Dalam bahasa Indonesia, kata beberapa sudah menunjukkan makna banyak sehingga sebaiknya penulis menggunakan frasa beberapa foto atau foto-foto.

- penggunaan diksi yang kurang tepat, seperti pada kalimat: Makanan cepat saji adalah makanan langsung menjadi pembelian seperti makanan di Mc. Donald, di KFC, di Pizza Hut. Kalimat ini tidak efektif karena diksi yang digunakan kurang tepat. Sebaiknya, makanan langsung menjadi pembelian diubah menjadi makanan langsung jadi dan dibeli. Selain itu, penggunaan kata depan di pada kalimat 
tersebut tidak perlu diulang, cukup sekali. Kalimat ini bisa diperbaiki menjadi Makanan cepat saji adalah makanan langsung jadi dan dibeli seperti makanan di Mc. Donald, KFC, Pizza Hut.

- kalimat yang tidak logis, seperti pada kalimat: Makanan tradisional adalah makanan masak diri sendiri. Kalimat ini tidak logis karena makanan bukanlah benda hidup yang bisa melakukan aktivitas memasak. Kalimat ini dapat diperbaiki menjadi: Makanan tradisional adalah makanan yag dimasak sendiri.

- kesalahan ejaan, yaitu penggunaan lambang bilangan yang kurang tepat, seperti pada kalimat: 2 makanan ini tidak hanya beda tentang cara memasak tapi juga kualitasnya. Bilangan pada awal kalimat ditulis dengan huruf. Jika bilangan tersebut lebih dari dua kata, susunan kalimat diubah agar bilangan yang tidak dapat ditulis dengan huruf itu tidak ada pada awal kalimat. Jadi, seharusnya angka 2 pada kalimat tersebut diubah menjadi huruf, sehingga menjadi: Dua makanan ini tidak hanya beda.

- penulisan konjungsi yang kurang tepat dan tidak baku, seperti tapi, konjungsi yang baku dari tapi adalah tetapi.

- kalimat yang tidak efektif, yang antara lain disebabkan tidak adanya pemisahan antarklausa dengan tanda koma, seperti pada kalimat: Dua makanan ini tidak hanya berbeda tentang cara memasaknya tetapi juga kualitasnya. Kalimat ini dapat diperbaiki menjadi: Dua makanan ini tidak hanya berbeda tentang cara memasaknya, tetapi juga kualitasnya.

- penggunaan konjungsi ganda, seperti: pada kalimat: Karena makanan tradisonal dimasak sendiri, sehingga makanan itu lebih cocok dengan seleranya daripada makanan cepat saji.

- Konjungsi karena dan sehingga pada kalimat ini adalah konjungsi intrakalimat sebab-akibat. Dalam satu kalimat kedua konjungsi tersebut tidak perlu digunakan secara bersamaan. Agar menjadi efektif, salah satu konjungsi 
tersebut dapat dihilangkan, sehingga menjadi: Karena makanan tradisonal dimasak sendiri, makanan itu lebih cocok dengan seleranya daripada makanan cepat saji.

- kesalahan penggunaan konjungsi antarkalimat dan intrakalimat, seperti pada kalimat: Karena makanan tradisional dimasak diri sendiri, sehingga makanan ini lebih cocok dengan seleranya daripada makanan cepat saji, tapi makanan cepat saji sudah menjadi pilihan kebanyakan orang-orang di zaman modern ini, karena baik hemat waktu untuk masak maupun kebutuhannya. Bagian kalimat yang bergaris bawah merupakan gabungan kalimat sebelum dan sesudahnya. Agar efektif, kalimat tersebut dapat dipecah dan diganti konjungsinya dari konjungsi tapi (intrakalimat) menjadi namun (antarkalimat). Selain itu, klausa karena baik hemat waktu untuk masak maupun kebutuhannya bisa diperbaiki menjadi karena hemat waktu. Kalimat tersebut dapat diperbaiki menjadi: Namun, makanan cepat saji sudah menjadi pilihan kebanyakan orang-orang di zaman modern ini karena hemat waktu.

- penjamakan ganda, seperti pada frasa kebanyakan orangorang. Kesalahan tersebut dapat diperbaiki menjadi kebanyakan orang atau orang-orang.

- penggunaan diksi yang kurang tepat, seperti pada kalimat: Menurut data-data kepolisian RI pada tahun 1980 ditemukan fakta bahwa 50\% kecelakaan yang menimbulkan korban jiwa dari pengendara sepeda motor disebabkan oleh luka kepala. Penggunaan diksi menurut pada kalimat ini kurang tepat karena objek yang dirujuk oleh kata tersebut berupa benda bukan manusia. Diksi yang tepat untuk menggantinya yaitu berdasarkan. Agar lebih efektif, perlu ditambahkan tanda koma setelah tahun 1980 dan susunan kalimatnya juga bisa diubah. Kalimat ini dapat diperbaiki menjadi: Berdasarkan data-data kepolisian RI pada tahun 1980, ditemukan fakta bahwa 50\% kecelakaan pengendara 
sepeda motor yang menimbulkan korban jiwa disebabkan oleh luka kepala. Penggunaan diksi yang kurang tepat juga dapat dilihat pada kalimat: Dia mempunyai satu tanda lalat yang besar di alis. Dalam bahasa Indonesia diksi tanda lalat bisa diganti tahi lalat, sehingga kalimat tersebut bisa diperbaiki menjadi: Dia mempunyai satu tahi lalat yang besar di alis. Contoh lainnya adalah kalimat: Ibu saya tidak bagus tentang masak makanan tapi dia sangat rajin dan bussiness yang pintar. Pada kalimat ini, dijumpai kata bagus untuk menyifatkan keterampilan memasak dan kata bussiness untuk menerjemahkan kata pebisnis. Diksi yang tepat untuk menggantinya adalah pandai dan pebisnis. Sebagai tambahan, pada kalimat ini juga ditemukan kesalahan berupa ketiadaan tanda koma untuk memisahkan anak kalimat yang mendahului induk kalimat dan penggunaan preposisi yang kurang tepat. Preposisi tentang sebaiknya diganti dengan dalam. Kalimat tersebut dapat diperbaiki menjadi: Ibu saya tidak pandai dalam memasak makanan, tetapi dia sangat rajin dan pebisnis yang pintar.

- pengaruh bahasa asing pada kalimat bahasa Indonesia, seperti pada kalimat: Saya rindu ibu saya sekali. Susunan kalimat ini terpengaruh susunan kalimat dalam bahasa Inggris, yang merupakan terjemahan dari bahasa Inggris: I miss my mother very much. Seharusnya, susunan kalimat yang benar dalam bahasa Indonesia adalah Saya rindu sekali ibu saya atau Saya sangat rindu ibu saya.

\section{5) Kesalahan-kesalahan pada lembar kerja Subjek 5 dari Vietnam:}

- susunan frasa yang terbalik, seperti ikan tubuh. Dalam bahasa Indonesia frasa berstruktur DM (DiterangkanMenerangkan) sehingga frasa ikan tubuh dapat diperbaiki menjadi tubuh ikan.

- ketiadaan konjungsi untuk menghubungkan dua klausa, seperti pada kalimat: Potong kecil-kecil, lebih nyaman 
untuk makan. Kalimat ini terdiri atas dua klausa, yaitu (1) potong kecil-kecil dan (2) lebih nyaman untuk makan. Pada kalimat tersebut tidak terdapat konjungsi untuk menghubungkan kedua klausa tersebut, padahal keduanya dapat dihubungkan dengan konjungsi sebab-akibat, yaitu supaya atau agar.

- penggunaan diksi yang kurang tepat, seperti pada klausa: lebih nyaman untuk makan, yaitu diksi nyaman dan makan. Diksi nyaman lebih tepat diganti mudah. Sedangkan verba makan sebaiknya diganti dengan dimakan. Kalimat (x) dapat diperbaiki menjadi: Potong kecil-kecil agar lebih mudah untuk dimakan! Kesalahan penggunaan diksi yang kurang tepat juga dijumpai pada kalimat: Setelah selesai, dapat taburi dengan irisan daun bawang, sebagai dekorasi dan tidak berminyak. Seharusnya, diksi taburi diganti dengan ditaburi dan diksi dekorasi diganti dengan hiasan. Kalimat ini bisa diperbaiki menjadi: Setelah selesai, dapat ditaburi dengan irisan daun bawang sebagai hiasan agar tidak berminyak.

- urutan yang tidak paralel, seperti pada kalimat: Masukkan rempah-rempah diasinkan 10 menit, dapat menghilangkan bau ikan dan lebih lezat. Urutan yang tidak paralel yaitu menghilangkan bau ikan dan lebih lezat. Agar efektif, perlu ditambah satu verba lagi, misalnya verba menjadikan.

- penggunaan preposisi dan konjungsi yang kurang tepat, seperti pada kalimat: Masukkan rempah-rempah diasinkan 10 menit, dapat menghilangkan bau ikan dan lebih lezat. Kalimat ini tidak efektif karena ada pelesapan konjungsi dan preposisi. Sebaiknya, kalimat ini ditambah dengan konjungsi dan dan preposisi untuk. Perbaikan kalimat tersebut adalah: Masukkan rempah-rempah dan diasinkan 10 menit untuk menghilangkan bau ikan dan menjadikannya lebih lezat!

- penggunaan ejaan yang tidak tepat, berupa penggunaan huruf kapital, tanda koma, dan tanda titik yang kurang 
tepat. Kesalahan penggunaan huruf kapital dijumpai pada kalimat-kalimat: (1) belajar bahasa mandarin ternyata bermanfaat bagi pengembangan otak besar, (2) hal ini sudah sejak lama terus menerus dibuktikan oleh penelitian ilmiah. (3) cha De Lin melakukan penelitian terhadap IQ anak dari lima negara yakni: inggris, Amerika, Perancis, Jerman-barat, dan Eropa nilai rata-ratanya 100, sedangkan IQ rata-rata anak-anak Jepang ialah 111, sebabnya ialah anak-anak Jepang telah mempelajari huruf kanji (aksara mandarin). Huruf kapital dipakai untuk mengawali sebuah kalimat dan sebagai huruf pertama nama bangsa, suku bangsa, dan bahasa. Kalimat (1) salah karena tidak diawali dengan huruf kapital dan terdapat nama bahasa yang tidak diawali huruf kapital. Dalam karangan responden, kalimat (2) disatukan dengan kalimat sebelumnya, seharusnya kedua kalimat tersebut dipisah dengan kalimat karena masing-masing memiliki gagasan utama sendiri. Kalimat (3) juga tidak diawali dengan huruf kapital. Selain itu, pada kalimat (3), huruf kapital tidak dipakai sebagai huruf pertama dalam unsur nama orang dan nama negara, yaitu cha De Lin dan inggris. Kesalahan penggunaan huruf kapital tidak hanya dijumpai pada ketiga kalimat di atas, tetapi juga di kalimat lain, seperti pada penulisan nama bulan yang seharusnya menggunakan huruf kapital. Selain itu, juga dijumpai beberapa kesalahan penggunaan tanda koma, seperti pada kalimat: (1) Pada bulan Mei 1982 Pakar Psychology Dr cha De Lin di majalah yang tersohor di seluruh dunia, mempublikasikan sebuah yang artikel yang menggegerkan dunia dan kalimat: (2) Oleh karena itu marilah belajar bahasa mandarin, kerena dengan bahasa mandarin kita dapat berkomunikasi dengan lebih banyak orang di seluruh dunia dan meningkatkan. Kesalahan kalimat (1) terletak pada peletakan tanda koma yang tidak tepat dan ketiadaannya. Tanda koma dipakai untuk mengapit keterangan tambahan yang sifatnya tidak membatasi. Pada kalimat tersebut, Dr Cha De Lin merupakan 
keterangan tambahan (apositif) dari Pakar Psychology, sehingga harus diapit tanda koma. Selain itu, pada kalimat tersebut dijumpai tanda koma yang memisahkan subjek Pakar Psychology, Dr cha De Lin dan predikat mempublikasikan. Adapun kalimat (2) terdapat kesalahan karena ketiadaan koma setelah tanda hubung (konjungsi) antarkalimat oleh karena itu. Seharusnya, tanda koma dipakai di belakang kata atau ungkapan penghubung antarkalimat yang terdapat pada awal kalimat.

- penggunaan istilah asing dalam kalimat bahasa Indonesia, seperti istilah psychology. Dalam bahasa Indonesia, istilah tersebut diserap menjadi psikologi. Apabila tetap menggunakan istilah asing tersebut, seharusnya, tulisannya dicetak miring.

\section{6) Kesalahan-kesalahan pada lembar kerja Subjek 6 dari Vietnam:}

- kalimat yang tidak berpredikat, seperti pada kalimat: Fotomu yang dikirimkan kepada saya yang luar biasa. Sebuah kalimat yang baik harus mengandung subjek dan predikat, sementara kalimat tersebut hanya terdiri atas subjek, tanpa predikat. Agar mempunyai predikat, preposisi yang pada kalimat tersebut dihilangkan, sehingga menjadi: Fotomu yang dikirimkan kepada saya luar biasa.

- penggunaan verba pasif yang salah, seperti pada kalimat: Saya senang sekali ketika kalian menarik tentang Kebudayaan Indonesia. Verba menarik pada klausa kedua, ketika kalian menarik Kebudayaan Indonesia, tidak tepat. Klausa tersebut dapat diperbaiki menjadi ketika kalian tertarik Kebudayaan Indonesia.

- susunan kalimat dan diksi yang kurang tepat, seperti pada kalimat: Kalian perlu semoga kepada mepelai laki-laki dan perempuan apa? Diksi dan susunan unsur pada kalimat tersebut kurang tepat. Sebaiknya, diksi semoga diganti dengan berdoa. Susunan unsur kalimatnya juga harus 
diubah atau diperbaiki menjadi: Kalian berdoa/berharap apa kepada mepelai laki-laki dan perempuan? Kesalahan diksi juga dijumpai pada kalimat: Menurut penelitian, betakaroten pada buah salak sangat tinggi daripada mangga 5 kali lebih besar. Diksi sangat pada kalimat tersebut kurang tepat karena disandingkan dengan daripada. Diksi yang tepat adalah lebih, bukan sangat.

- kesalahan ejaan, yaitu pada penggunaan tanda baca akhir. Kesalahan tersebut dijumpai pada kalimat: Apakah kalian masih ada kesempatan untuk lihat upacara yang lain. Kalimat ini merupakan kalimat pertanyaan (introgatif), sehingga tanda baca akhirnya berupa tanda tanya, bukan tanda titik. Tanda titik digunakan untuk mengakhiri kalimat berita (deklaratif). Dengan demikian, kalimat tersebut dapat diperbaiki menjadi: Apakah kalian masih ada kesempatan untuk lihat upacara yang lain?

- kesalahan ejaan juga ditemukan pada penggunaan tanda koma dan penulisan kata depan di. Kesalahan tersebut dijumpai pada kalimat: Buah salak bermacam-macam, seperti salak sidimpuan dari Sumatra Utara, salak condet dari Jakarta, salak pondoh dari Yogyakarta dan salak Bali dari Bali, tapi diantaranya salak pondoh di Yogyakarta paling banyak dan dan paling populer di pasaran. Terdapat dua kesalahan pada kalimat ini, yaitu kesalahan (ketiadaan) tanda koma dalam perincian dan penulisan $d i$ sebagai kata depan. Tanda koma dipakai di antara unsur unsur dalam suatu perincian atau pembilangan. Seharusnya, sebelum perincian yang terakhir, disisipi tanda koma. Pada kalaimat tersebut juga terdapat kesalahan penulisan di sebagai kata depan. Sebagai kata depan, penulisan di dipisah dengan unsur yang mengikutinya. Frasa diantaranya seharusnya ditulis di antaranya. Perbaikan kalimat tersebut dapat dilakukan menjadi: Buah salak bermacammacam, seperti salak sidimpuan dari Sumatra Utara, salak condet dari Jakarta, salak pondoh dari Yogyakarta dan salak bali dari Bali, tapi (tetapi) di antaranya salak pondoh 
di Yogyakarta paling banyak dan paling populer di pasaran.

- penggunaan diksi yang kurang tepat, seperti pada kalimat: Menurut penelitian, mendengarkan musik sampil belajar dapat meningkatkan efektifitas belajar. Diksi efektifitas pada kalimat ini tidak tepat karena tidak baku. Diksi tersebut tidak diserap dari kata effectivity, tetapi effectiveness. Padanan kata yang baku dari effectiveness adalah keefektifan. Kalau ingin tetap menggunakan diksi efektifitas, seharusnya menggunakan kata bakunya,yaitu efektivitas. Kesalahan diksi yang lain juga dijumpai pada kalimat: Saya mau deskripsi tentang botol air. Diksi deskripsi tidak tepat digunakan sebagai predikat dalam kalimat ini karena deskripsi merupakan nomina. Kalimat tersebut memerlukan predikat berupa verba. Diksi yang tepat untuk menggantikannya adalah mendeskripsikan.

- penggunaan konjungsi yang kurang tepat, seperti pada kalimat: (1) Menurut penelitian, mendengarkan musik sampil belajar dapat meningkatkan efektifitas belajar.(2) Tetapi kita harus pintar ketika memilih jenis musik untuk belajar. Konjungsi tetapi bukanlah konjungsi antarkalimat yang dapat menghubungkan dua kalimat. Konjungsi yang tepat untuk menghubungkan kedua kalimat tersebut adalah namun atau akan tetapi, sehingga kalimatnya menjadi: (1) Menurut penelitian, mendengarkan musik sampil belajar dapat meningkatkan efektifitas belajar. (2) Namun, kita harus pintar ketika memilih jenis musik untuk belajar.

- kalimat tidak berpredikat, seperti pada kalimat: Kita tidak bisa jenis musik seperti musik rock, pop ketika sedang membaca buku atau belajar karena jenis-jenis itu akan mengganggu otak sehingga otak tidak bisa bekerja menjadi maksimal. Klausa pertama pada kalimat ini, kita tidak bisa jenis musik seperti musik rock, pop, tidak memiliki predikat. Klausa tersebut perlu diberi predikat berupa verba. Verba yang tepat adalah mendengarkan karena objeknya jenis 
musik.

- penggunaan konjungsi yang berlebihan, seperti pada kalimat: Kita tidak bisa jenis musik seperti musik rock, pop ketika sedang membaca buku atau belajar karena jenis-jenis itu akan mengganggu otak sehingga otak tidak bisa bekerja menjadi maksimal. Untuk memperbaikinya, kalimat tersebut dapat dipecah menjadi dua kalimat: (1) Kita tidak bisa mendengarkan jenis musik seperti musik rock dan pop ketika sedang membaca buku atau belajar. (1) Jenis musik itu akan mengganggu otak sehingga otak tidak bisa bekerja secara maksimal.

\section{7) Kesalahan-kesalahan pada lembar kerja Subjek 7 dari Vietnam:}

- kalimat yang tidak lengkap (tidak mengandung predikat), seperti pada kalimat: Hitam dan cokelat. Kalau diperhatikan, seharusnya ada kalimat sebelumnya yang memiliki hubungan dengan kalimat tersebut, yaitu Rambut dia sering ada 2 warna. Kalimat: Hitam dan cokelat adalah keterangan tambahan (apositif) dari kalimat sebelumnya. Agar benar, kalimat tersebut dapat diperbaiki menjadi: Rambut dia sering ada 2 warna, hitam dan cokelat atau Rambutnya ada 2 warna, hitam dan cokelat.

- kesalahan ejaan, yaitu kesalahan dalam penggunaan huruf kapital, seperti pada kalimat: Pada tanggal 3 april tahun 2017, Spa "My Beauty" akan membuka cabang baru di distrik 1, Kota Ho Chi Menh. Huruf kapital dipakai sebagai huruf awal nama bulan. Seharusnya bulan april ditulis dengan huruf awal kapital, yaitu April.

- penggunaan diksi yang tidak tepat, seperti pada kalimat: Dengan saya, dia sangat ganteng. Penggunaan diksi dengan pada kalimat ini tidak tepat. Seharusnya, diksi dengan diganti dengan menurut. 


\section{8) Kesalahan-kesalahan pada lembar kerja Subjek 8 dari} Timor Leste:

- penulisan frasa preposisional yang salah, yakni frasa disana. Penulisan disana tidak tepat karena di- pada frasa tersebut merupakan kata depan. Penulisan di- sebagai kata depan dipisah dari kata yang mengikutinya sehingga penulisan yang tepat adalah di sana.

- diksi yang tidak tepat, seperti pada kalimat: Sekian dulu, Sally, saya tunggu pembalasan dari kamu, salam dari Ibu Simpson.Diksi pembalasan pada kalimat ini tidak tepat digunakan karena bermakna proses membalas. Seharusnya, kata yang digunakan adalah balasan yang bermakna hasil dari membalas.

- kalimat yang tidak bersubjek, seperti pada kalimat: Dalam rangka saya menulis persuasi propaganda sebagai topik saya karena saya melihat situasi nyata di era globalisasi sekarang. Kalimat ini mempunyai dua klausa: (1) dalam rangka saya menulis persuasi propaganda sebagai topik saya dan (2) saya melihat situasi nyata di era globalisasi sekarang. Klausa pertama tidak ada subjeknya. Untuk memperjelas subjek, sebaiknya, frasa dalam rangka dibuang. Kalimat tersebut dapat diperbaiki menjadi: Saya menulis persuasi propaganda sebagai topik karena saya melihat situasi nyata di era globalisasi sekarang.

- kesalahan ejaan, yaitu kesalahan penggunaan huruf kapital dan tanda baca yang mengakibatkan kalimat terlalu panjang. Sebaiknya, kalimat panjang bisa dijadikan beberapa kalimat dengan penggunaan tanda baca yang tepat. Kesalahan tersebut dapat dilihat pada rangkaian kalimat: Dalam rangka saya menulis persuasi propaganda sebagai topik saya karena saya melihat situasi nyata di era globalisasi sekarang bahwa sebagian kita, ada yang belum punya kesadaran terhadap lingkuangan yang ada, kadang membuang sampah sembarangan di sekitar lingkungannya meskipun Pemerintah sudah mensosialisasi tentang 
efek membuang sampah sembarang dan Pemerintah juga memasang tempat sampah di tempat jalan maupun di sekitar kita. kalau kita membuang sampah sembarang akan mengakibatkan terjadi erosi, banjir dan secara tidak langsung kita sendirilah yang menghancurkan bangsa dan negara karena kita sudah membunuh ekosistem yang sebagai sumber kekayaan negara karena ini adalah roda ekonomi pemerintah untuk menjalankan harapan bagi bangsa dan negara yang sejahtera. Sebenarnya, rangkaian kalimat tersebut adalah paragraf. Karena tanda bacanya tidak jelas, satu paragraf itu hanya menjadi satu kalimat. Selain itu, penggunaan huruf kapital juga belum tepat. Untuk memperbaiki rangkaian kalimat tersebut, penggunaan tanda baca dan huruf kapital perlu diperhatikan dengan saksama, menjadi seperti berikut.

Saya menulis persuasi propaganda sebagai topik karena melihat situasi nyata di era globalisasi sekarang. Sebagian dari kita, ada yang belum punya kesadaran terhadap lingkungan yang ada. Kadang membuang sampah sembarangan di sekitar lingkungannya meskipun pemerintah sudah menyosialisasi tentang efek membuang sampah sembarang. Pemerintah juga memasang tempat sampah di jalan maupun di sekitar kita.

Kalau kita membuang sampah sembarang, akan mengakibatkan terjadi erosi, banjir. Secara tidak langsung kita sendirilah yang menghancurkan bangsa dan negara karena sudah membunuh ekosistem yang sebagai sumber kekayaan negara. Hal ini adalah roda ekonomi pemerintah untuk menjalankan harapan bagi bangsa dan negara yang sejahtera. 
9) Kesalahan-kesalahan pada lembar kerja Subjek 9 dari Thailand:

- penggunaan tanda baca akhir (final punctuation), seperti pada kalimat: Beli kain kaos dan pilih kain yang anda sukai. Pada saat menuliskan kalimat perintah, seharusnya, penulis menggunakan tanda baca akhir tanda seru (!). Kalimat ini dapat diperbaiki menjadi: Beli kain kaos dan pilih kain yang anda sukai!

- kalimat yang tidak logis, seperti dapat dilihat pada kalimat: Sebelumnya, harus ukur badan yang ingin menjahit atau ukur pada baju. Kalimat ini tidak logis karena badan adalah benda mati yang tidak bisa menjahit. Seharusnya, verba menjahit diganti dengan verba dijahit karena badan adalah objek yang dikenai pekerjaan.

- reduplikasi susunan frasa yang tidak tepat, seperti frasa orang tua-tua. Dalam reduplikasi frasa bahasa Indonesia konstituen yang diulang adalah konstituen inti, yaitu kata pertama dalam frasa tersebut. Frasa tersebut dapat diperbaiki menjadi orang-orang tua.

- penggunaan konjungsi yang berlebihan, seperti pada kalimat: Oleh itu, marilah minum obat dengan air putih karena air putih bebas dari kandungan bahan kimia sehingga tidak menimbulkan kontraksi. Kalimat ini terdiri atas tiga klausa, yaitu (1) marilah minum obat dengan air putih, (2) air putih bebas dari kandungan bahan kimia, dan (3) tidak menimbulkan kontraksi. Dalam kalimat tersebut juga terdapat tiga konjungsi, yaitu oleh itu, karena, dan sehingga. Konjungsi oleh itu tidak lazim dalam bahasa Indonesia, tetapi lazim dalam bahasa Melayu. Konjungsi antarkalimat yang tepat dalam bahasa Indonesia adalah oleh karena itu. Sebaiknya, konjungsi sehingga diganti dengan konjungsi dan agar lebih efektif dan tidak ganda konjungsi sebab-akibat dalam satu kalimat. Dilihat dari konteksnya, kalimat tersebut termasuk kalimat ajakan (perintah) sehingga tanda baca akhirnya berupa tanda 
seru (!), bukan titik (.). Kalimat tersebut dapat diperbaiki menjadi: Oleh karena itu, marilah minum obat dengan air putih karena air putih bebas dari kandungan bahan kimia sehingga tidak menimbulkan kontraksi!

\section{0) Kesalahan-kesalahan pada lembar kerja Subjek 10 dari Mexico:}

- pemerincian yang tidak tepat, seperti pada kalimat: Ini adalah kertas meja kayu dengan logam. Kalimat ini ambigu karena tidak ada tanda bacanya. Mungkin maksud penulis adalah hendak menunjukkan kertas dan meja yang terbuat dari kayu dan logam. Namun, karena tanda bacanya tidak ada, kalimatnya jadi membingungkan pembaca. Kalau maksud penulis (Subjek 10) sama dengan peneliti (analis), kalimat tersebut bisa diperbaiki menjadi: Ini kertas dan meja yang terbuat dari kayu dan logam.

- susunan kata yang tidak tepat, seperti pada frasa kayu meja. Seharusnya, frasa dalam bahasa Indonesia berstruktur DM sehingga frasa yang tepat adalah meja kayu yang bermakna meja yang terbuat dari kayu.

- penggunaan diksi yang kurang tepat, seperti pada kalimat: (1) Kayu meja ada warna putih dan punya nomor 5. (2) Kursi ada warna biru. Diksi ada pada kalimat (1) dan (2) kurang tepat digunakan. Dalam Kamus Besar Bahasa Indonesia kata ada memang bisa diartikan mempunyai, tetapi kurang lazim digunakan dalam bahasa Indonesia. Sebaiknya, kata ada diganti dengan kata mempunyai. Selain dengan mengganti kata ada dengan mempunyai, kedua kalimat tersebut dapat diperbaiki dengan cara menyederhanakan unsurunsur pembentuknya menjadi: (1) Kayu meja berwarna putih dan berangka 5. (2) Kursi berwarna biru.

- pengaruh bahasa asing, seperti pada kalimat: Ini kertas meja banyak sangat membosankan. Susunan kalimat ini terpengaruh bahasa Spanyol. Responden Adrian memang berasal dari Spanyol sehingga susunan kalimat yang dia 
tulis sama dengan kalimat bahasa Spanyol. Dalam bahasa Indonesia kalimat tersebut dapat diperbaiki menjadi: Ini banyak kertas di meja yang sangat membosankan.

- kesalahan ejaan, yaitu penggunaan tanda baca akhir, yang dijumpai di seluruh karangan Adrian.

Ini adalah kertas meja kayu dengan logam

Kayu meja ada warna putih dan punya nomor 5

Kursi ada warna biru

Ini kertas meja banyak sangat membosankan

Karangan tersebut merupakan karangan deskripsi. Kalimat-kalimatnya berbentuk kalimat berita sehingga tanda baca akhirnya berupa titik.

\section{1) Kesalahan-kesalahan pada lembar kerja Subyek 11 dari Polandia:}

- penggunaan diksi yang kurang tepat, seperti pada kalimat: Saya akan deskripsi buku berjudul "Cube Libre" ditulis Joeur Sqnchez. Diksi deskripsi tidak tepat digunakan sebagai predikat dalam kalimat tersebut karena predikat yang dibutuhkan adalah verba, bukan nomina. Seharusnya, predikat yang digunakan adalah verba mendeskripsikan, sehingga kalimatnya menjadi: Saya akan mendeskripsikan buku berjudul "Cube Libre” (yang) ditulis Joeur Sqnchez.

- penghilangan preposisi, seperti pada kalimat: Saya akan mendeskripsikan buku berjudul "Cube Libre" (yang) ditulis Joeur Sqnchez. Preposisi yang dihilangkan dalam kalimat tersebut adalah preposisi yang sebelum klausa ditulis oleh Joeur Sqnchez. Seharusnya, kalimat tersebut diperbaiki menjadi: Saya akan mendeskripsikan buku berjudul "Cube Libre" yang ditulis Joeur Sqnchez.

- kalimat tidak berpredikat, seperti pada kalimat: Buku ini tentang kehidupan sehari-hari di negara Cube. Kalimat ini tidak memiliki predikat. Predikat yang dibutuhkan untuk menjelaskan keterangan kehidupan sehari-hari di negara 
Cube adalah bercerita atau berkisah. Kalimat tersebut dapat diperbaiki menjadi: Buku ini berkisah tentang kehidupan sehari-hari di negara Cube.

\section{Kesimpulan}

BIPA merupakan pembelajaran bahasa Indonesia yang subjeknya adalah pembelajar asing. BIPA dipandang lebih pada faktor pembelajarnya. Orang-orang yang menjadi subjek pembelajaran BIPA adalah orang asing, bukan penutur bahasa Indonesia (Kusmiatun 2016, 1). Kesalahan berbahasa adalah bagian dari sebuah percakapan yang menyimpang dari beberapa norma atau aturan penggunaan bahasa yang dipilih (Dulay, Burt, dan Krashen 1982, 277). Kesalahan berbahasa adalah penyimpangan yang tampak pada tata bahasa penutur asli yang mencerminkan kompetensinya dalam berbahasa (Brown 1994, 205).

Dalam penelitian ini peneliti meneliti kesalahan sintaksis bahasa tulis pembelajar BIPA. Kesalahan-kesalahan tersebut antara lain penggunaan preposisi yang tidak tepat, susunan kata yang tidak tepat, penjamakan yang ganda, kalimat yang ambigu, kalimat yang tidak logis, kalimat yang tidak bersubjek, kalimat yang tidak berpredikat, kalimat yang tidak bersubjek dan berpredikat (kalimat buntung), penghilangan konjungsi, kesalahan ejaan, dan penggunaan istilah asing. 


\section{BIBLIOGRAFI}

Andayani. 2012. "Keterampilan Berbahasa Mahasiswa Peserta BIPA di Perguruan Tinggi." Jurnal Kajian Linguistik dan Sastra 19 (1): 11.

----. 2010. "The Effectiveness of Direct Learning in Ability Writing in Teaching Indonesian to Speakers of Other Languages." Jurnal Kajian Linguistik dan Sastra 24 (4): 112-122.

Brown, H. Douglas. 1994. Principles of Language Learning and Teaching. New Jersey: Prentice Hall Regents.

Chaer, Abdul. 1994. Linguistik Umum. Jakarta: Rineka Cipta.

Dulay, H., Burt, M. \& Krashen, S. 1982. Language Two. New York: Oxford University Press.

Keraf, Gorys. 1978. Komposisi. Flores: Nusa Indah.

Kusmiatun, Ari. 2016. Mengenal BIPA (Bahasa Indonesia bagi Penutur Asing) dan Pembelajarannya. Yogyakarta: K-Media.

Mahmud, H. 2011. Metode Penelitian Pendidikan. Bandung: Pustaka Setia.

Muliastuti, Liliana. 2010. "Pengembangan Materi Ajar Bahasa Indonesia Bagi Penutur Asing (BIPA)." Paper disampaikan dalam Konferensi Internasional Pengajaran Bahasa Indonesia Bagi Penutur Asing, 29-31 Juli 2010 di Universitas Indonesia. Nasution, S. 1992. Metode Penelitian Naturalistik-Kualitatif. Bandung: Tarsito.

Pamungkas, Sri. 2012. Bahasa Indonesia dalam Berbagai Perspektif. Yogyakarta: Penerbit Andi.

Radford, Andrew. 2004. English Syntax: An Introduction. Cambridge, UK: Cambridge University Press.

---- 1998. Syntax: A Minimalist Introduction. Australia: Cambridge University Press.

Setyawati, Nanik. 2010. Analisis Kesalahan Berbahasa Indonesia: Teori dan Praktik. Surakarta: Yuma Pustaka.

Sutopo, H. B. 2006. Metodologi Penelitian Kualitatif Dasar Teori dan Terapannya dalam Penelitian. Surakarta: Universitas 
Mokh. Yahya; Andayani; Kundharu Saddhono

Sebelas Maret.

Suyitno, Imam. 2007. "Pengembangan Bahan Ajar Bahasa Indonesia untuk Penutur Asing (BIPA) berdasarkan Hasil Analisis Kebutuhan Pelajar." Wacana, Journal of The Humanities of Indonesia 9 (1): 62-78.

Yule, George. 2014. Kajian Bahasa. Yogyakarta: Pustaka Pelajar. 